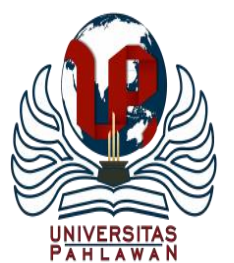

Edukatif : Jurnal Ilmu Pendidikan Volume 3 Nomor 2 Tahun 2021 Halm 447 - 455 EDUKATIF: JURNAL ILMU PENDIDIKAN

Research \& Learning in Education

https:/ledukatif.org/index.php/edukatif/index

\title{
Utilization of Information Technology during the Covid-19 pandemic: Student's Perception of Online Lectures
}

\author{
Ubaedillah $^{1 \bowtie}$, Damar Isti Pratiwi ${ }^{2}$ \\ Universitas Muhadi Setiabudi, Indonesia ${ }^{1}$ \\ Politeknik Perkeretaapian Indonesia, Indonesia ${ }^{2}$ \\ E-mail : $\underline{\text { ubaedillah@umus.ac.id }}{ }^{1}, \underline{\text { damar@ ppi.ac.id }}^{2}$
}

\begin{abstract}
Abstrak
Peraturan kebijakan perkuliahan jarak jauh saat pandemi Covid-19 membuat dosen di Universitas Muhadi Setiabudi harus mampu memanfaatkan teknologi informasi yang tersedia saat ini sebagai sarana mengajar, agar mahasiswa tetap mendapatkan materi perkuliahan yang dibutuhkan. Penelitian ini bertujuan untuk mengetahui persepsi mahasiswa tentang pemanfaatan teknologi informasi dalam perkuliahan online di Universitas Muhadi Setiabudi pada masa pandemi Covid19. Penelitian ini menggunakan pendekatan qualitatif melalui survey dengan sampel yang digunakan dalam penelitian ini adalah seluruh mahasiswa Universitas Muhadi Setiabudi semester dua dan semester empat Program Studi Pendidikan Guru Sekolah Dasar yang berjumlah 145 siswa. Intrumen yang digunakan ialah Semi-structured Interviews melalui wawancara dengan 20 mahasiswa. Hasil pada penelitian ini menunjukan bahwa media yang paling banyak dimanfaatkan dalam perkuliahan online di Universitas Muhadi Setiabudi adalah Google Classroom dan Group WhatsApp, hal ini karena aplikasi ini mudah digunakan oleh berbagai kalangan dan usia. Berdasarkan hasil survei, respondents berkendala dalam mengikuti perkuliahan online karena masing-masing 50\% tidak mempunyai leptop dan hanya mengandalkan handphone, $61,5 \%$ belum pernah menggunankan teknologi informasi sebelum covid-19, dan $80 \%$ mahasiswa terkendala sinyal dan biaya untuk membeli quota. Disisi lain, pemanfaatan teknologi informasi dapat mempercepat proses transformasi digital pendidikan di Universitas Muhadi Setiabudi dan seluruh perguruan tinggi di Indonesia.
\end{abstract}

Kata Kunci: teknologi informasi, covid-19, perkuliahan online.

\begin{abstract}
During the Covid-19 pandemic, the regulation of distance lecturing policies allowed Muhadi Setiabudi University lecturers to be able to use currently available information technology as a teaching tool in order for students to receive the required lecture content. During the Covid-19 pandemic, this study aims to assess students' impressions of using information technology in online lectures at Muhadi Setiabudi University. The sample used in this research was all Muhadi Setiabudi University students in the second and fourth semesters of the Primary School Teacher Education Study Program, totaling 145 students, using a qualitative approach through a survey. Interviews with 20 students were conducted using a semi-structured interviewing method. According to the findings of this research, Google Classroom and WhatsApp Community are the most commonly used media in online lectures at Muhadi Setiabudi University, owing to their ease of use by a broad range of groups and ages. According to the survey results, 50 percent of respondents do not have a mobile phone and rely solely on their cellphones, 61.5 percent have never used information technology before Covid-19, and 80 percent of students are limited by signals and costs to purchase quotas. On the other hand, information technology will help Muhadi Setiabudi University and all Indonesian universities accelerate their digital transformation processes.
\end{abstract}

Keywords: information technology, covid-19, online lectures

Copyright (c) 2021 Ubaedillah, Damar Isti Pratiwi

$\triangle$ Corresponding author

Email : ubaedillah@umus.ac.id

DOI : https://doi.org/10.31004/edukatif.v3i2.320

ISSN 2656-8063 (Media Cetak)

ISSN 2656-8071 (Media Online)

Edukatif : Jurnal Ilmu Pendidikan Vol 3 No 2 Tahun 2021 p-ISSN 2656-8063 e-ISSN 2656-8071 
448 Utilization of Information Technology during the Covid-19 pandemic: Student's Perception of Online Lectures - Ubaedillah, Damar Isti Pratiwi

DOI: https://doi.org/10.31004/edukatif.v3i2.320

\section{INTRODUCTION}

The spread of Covid-19 has caused concern around the world, including in Indonesia. Since Covid-19 is a new virus, many people are unfamiliar with it and are uncertain how to deal with it. Since there is currently no treatment or vaccine for Covid-19, the entire world focus on avoiding it and raising positive patient (Culp, 2020). With the Covid-19 virus, the government has implemented several measures to halt the spread of the epidemic, including the closure of areas designated as a red zone for the virus's spread and physical quarantine to prevent the virus from spreading by physical touch. Various health pandemics have also been published by the Government of the Republic of Indonesia. The government, led by the Indonesian Ministry of Health, implements the protocol during the pandemic (Mendikbud, 2020). The rise in positive Covid-19 cases has an impact not only on the economy but also on education. Since educators, students, and parents are not prepared, introducing the physical distancing program (Velavan \& Meyer, 2020), which then becomes the foundation for incorporating learning at home through information technology, frequently shocks educators, students, and parents. Educators are surprised that they must adjust the learning system, formerly based on face-to-face instruction but is now entirely online (Atmojo \& Nugroho, 2020).

Indonesia's strategy of introducing online education in schools and universities is a reaction to the Covid-19 pandemic that has swept the globe (Budianto \& Arifani, 2021). The Republic of Indonesia's Ministry of Education and Culture supports the implementation of an online learning process. It is under the Minister of Education and Culture of the Republic of Indonesia's Circular No. 3 of 2020 on Corona Virus Disease Prevention (COVID-19) in the Education Unit, as well as the Secretary-General of the Minister of Education and Culture's Letter No. 35492 / A.A5 / HK / 2020 on Corona Virus Diffusion Prevention (Covid19) (Mendikbud, 2020). Besides, the respective Regional Governments that house Tertiary Education Institutions issue circulars and appeals.

The use of information technology to introduce online lectures is a viable option. Educators use various information media to conduct online learning (Durriyah \& Zuhdi, 2018). Several information technology tools can support online learning programs while also forcing lecturers to become information technology literate. (Zam Zam Al Arif, 2019). E-learning refers to using information and communication technologies to allow students to study whenever and wherever. (Hamadeh, 2020). There are two forms of e-learning: synchronous and asynchronous. Synchronous refers to events happening at the same time. Educators and students also participate in the learning process simultaneously (Durriyah \& Zuhdi, 2018). Digital classrooms are a popular term for synchronous training. Asynchronous suggests that something is not happening at the same time. Students may learn at their own pace, with educators supplying materials (Safdari, 2021). Edmodo is a stable framework that can be used for both teachers and students/students. It is a social network-based learning platform that makes it easier for teachers to build and manage virtual classes so that students can interact with classmates and teachers whenever and wherever they want (Fauzi, 2017). Saving time, keeping classes coordinated, and improving contact with students are only a few of the advantages of Edlink for lecturers (Kodrat, 2021). Moodle is a learning management system developed specifically for educators, managers, and students. Moodle, or Modular Object-Oriented Dynamic Learning Environment, is the acronym for Modular Object-Oriented Dynamic Learning Environment. Google Classroom, also known as Google Classroom, is a blended learning platform for education that allows teachers to build, exchange, and identify paperless assignments more efficiently (Iftakhar, 2016). Google Classroom is a Google-provided e-learning system that is accessible through the internet. This service is intended to help teachers develop and deliver assignments to students without paper (Al-Maroof \& Al-Emran, 2018). (Shams-Abadi et al., 2015) It is built for teachers, pupils, and their parents to use. Schoology has a similar presence to the social networking site Facebook. Facebook is a popular social networking site among teenagers, and even elementary school children are familiar with it. (Wang et al., 2011). Zoom is a free HD video and screen-sharing meeting software for up to 
100 users. Zoom is a video-based communication tool. These applications are compatible with a wide range of mobile devices, desktop computers, telephones, and room systems. (Budianto \& Arifani, 2021). Whatsapp is a text, speech, and video messaging app that is one of today's most widely used communication platforms (Gon \& Rawekar, 2017) - using WhatsApp is used to keep in touch with family friends any time and from anywhere. According to Niken, the Ministry of Communication and Information secretary-general (Hamat \& Hassan, 2019).

The majority of online learning studies concentrate on stand-alone instructional methodologies or methods, specific experiences within a blended learning program, and contrasts between classroom-based and completely online learning (Gon \& Rawekar, 2017). The learning from the home strategy was not adequately enforced during the Covid-19 pandemic, and according to the teacher's observations of the challenges, attitude, interpretation, appraisal, evaluation of the teacher are frequently highlighted. (Nashir \& Laili, 2021). Many quantitative and qualitative studies have been conducted to investigate online learning's efficacy (Gon \& Rawekar, 2017). Students and faculty use emerging technologies and platforms in all aspects of their daily lives, especially social media. However, only a small percentage of users use them for academic purposes (Atmojo \& Nugroho, 2020). According to (Budianto \& Arifani, 2021) stated about the learners' perceptions, practices, and challenges of using WhatsApp in East Java senior high schools summarized that WhatsApp is a primary tool for teaching and learning can be useful if teachers do not provide too many online tasks for their students. Providing timely online feedback on their students' online tasks becomes another merit of learning (Budianto \& Arifani, 2021).

Higher education institutions that formerly used the face-to-face approach for seminars, thesis instruction, and other research activities must now convert to a distance learning method (Khoshnevisan, 2020). It is known as distance learning in other languages (Hamat \& Hassan, 2019). It is also known as online learning, e-learning (electronic learning), and online education in other studies (in a network). It is now a challenge for lecturers, and students, whether they like it or not, must be prepared to face the new online learning world (Tirziu \& Vrabie, 2015). The distinction between face-to-face and distance learning has a different influence on student learning quality (Traxler, 2018).

Online lectures are implemented at Muhadi Setiabudi University, requiring all lecturers and students to be technologically literate. Lecturers must prepare material in the form of teaching materials and video tutorials before conducting online lectures. Likewise, students must study harder to understand the material provided by the lecturer in an online class. Information technology that lecturers need to develop innovatively will undoubtedly be beneficial in learning and the digital era. This study's findings are intended to provide an overview of the use of information technology in online lectures during the Covid-19 pandemic, the most commonly used medium in online lectures, and serve as guidance for lecturers at other universities selecting suitable information technology instructional media and teaching methods. Students' opinions on using information technology in online lectures will help Muhadi Setiabudi University or other universities manage the online learning process. It is recommended that other researchers conduct additional research in this related area of online learning and information technology use. Therefore, the questions leading the present research are 1). How is technology information in online lectures at Muhadi Setiabudi University during the Covid-19 pandemic? 2). How do students' perceptions of using information technology in online lectures at Muhadi Setiabudi University during the Covid-19 pandemic?.

\section{RESEARCH METHODS}

This research uses literature research and survey methods. Survey research was conducted by distributing questionnaires using google Forms. The primary data collection of this research is by distributing 
questionnaires to respondents (Creswell, 2014). This study's Respondents were 145 students of the Muhadi Setiabudi University in Semester 2 and 4 from the elementary school teacher education study program students. Then Semi-structured Interviews were used as a data collection instrument, and ten questions were given to 10 students to answer student perceptions about the use of information technology in online learning. The interview protocol was created as a follow-up to the questionnaire, which delved deeper into respondents'. Besides, those who took part in the interview session answered the following questions. 1) What Information Technology platforms do you use?, 2) What Information Technology platforms do you primarily use in online lectures?, 3) When do you usually use Information Technology in your online lectures?, 4) How frequently do you use Information Technology in your online lectures?, 5) What are the drawbacks of using Information Technology in online lectures?, 6) What are the benefits of using Information Technology in online lectures?, 7) How to prepare Information Technology in your online lectures?, 8) Who advised you to use Information Technology in your online lectures? 9) How can Information Technology assist your online lectures? 10) How can Information Technology influence your online lectures?.

\section{FINDING AND DISCUSSION}

All Indonesian tertiary institutions have adopted an online lecture implementation strategy in response to the worldwide Covid-19 pandemic. The Ministry of Education and Culture of the Republic of Indonesia supports the implementation of an online learning process. It follows the Minister of Education and Culture of the Republic of Indonesia's Circular No. 3 of 2020 on Corona Virus Disease Prevention (COVID-19). In the Education Unit and the Letter of the Secretary-General of the Minister of Education and Culture, number 35492 / A.A5 / HK / 2020, dated March 12, 2020, on the Prevention of Corona Virus Disease (Covid-19). The 5th point of the Ministry of Education and Culture circular letter No. 1 of 2020 concerning the Prevention of Corona Virus Disease (Covid-19) in Universities states, "Organizing distance learning is under the conditions of each PT and advises students to conduct learning from home with both synchronous and asynchronous online learning."(Mendikbud, 2020).

The implementation of the physical distancing policy later became the basis for implementing online lectures. Utilizing information technology that occurred suddenly shocked lecturers and students because they were not ready (Budianto \& Arifani, 2021). They were shocked because they had to change the learning, which has initially been face-to-face learning. Now all learning is done online. However, students must still be prepared for online learning. After three months of implementing online learning, many complaints were experienced by students because of the unpreparedness of the facilities owned by students. Teachers are encouraged to adapt their teaching-learning methods and prepare learning materials that enable students to learn from home now that the learning method that was previously done face-to-face in schools has gone online. Learning from home is based on the premise that students have unlimited access to learning materials and tools regardless of time or place. This activity is intended to encourage distance learning and make content delivery to students easier. Online learning necessitates effective instructional strategies and teachers' actions and attitudes in handling the teaching-learning process. (Nashir \& Laili, 2021).

Based on a circular about the Lecture System at Muhadi Setiabudi University, long-distance lectures have been carried out using the Google Classroom, Edmodo, EdLink, Schoology, Zoom Whatshap Group platforms. Based on the results of a survey on the use of online lecture applications, it is stated that the applications most used by Muhadi Setiabudi University lecturers and students can be seen in the following diagram: 


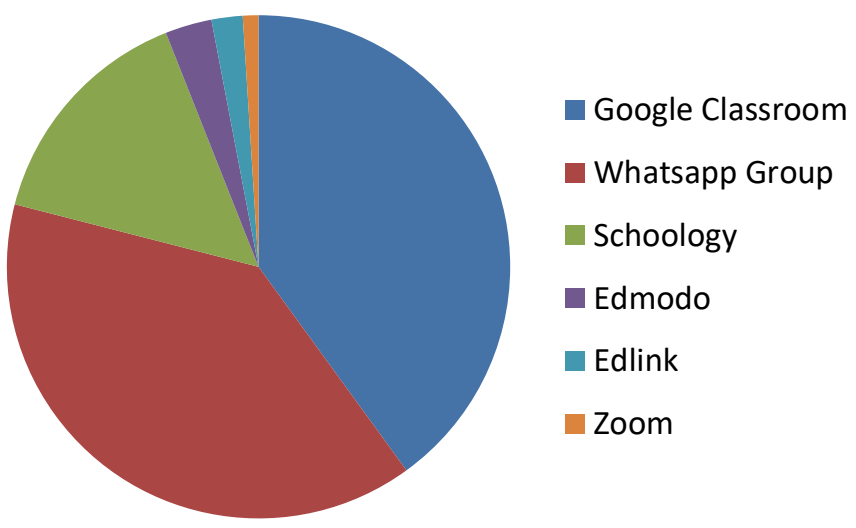

Figure 1: Information technology that is often used in distance learning

The results of Figure 1 above explain that the percentage of the types of platforms that are often used in distance learning at Muhadi Setiabudi University by lecturers and students is Google Classroom as much as $40 \%$, the second Whatsapp group as much as 39\%, the third Schoology as much as $15 \%$, then Edmudo 3\%, Edlink 2\%, and Zoom 1\%. The use of Google classroom and Whatsapp Group media is desirable to Muhadi Setiabudi University lecturers and students because it is effortless to understand and can be reached by signals and data packages owned by students. In order for lectures to be more interesting and students can understand the material presented, it is necessary to teach creativity from each lecturer, such as providing explanations of the material using videos.

From several information technologies in the form of digital mode platforms mentioned above, Google Classroom and Whatsapp are the most familiar among Muhadi Setiabudi University students and lecturers. It is proven that as many as $40 \%$ of lecturers use Google Classroom, and 39\% use Whatsapp in conducting distance learning. Before the Covid-19 pandemic, students and lecturers also had intensive communication and interaction related to learning through group Whatsapp. However, online learning during this pandemic should be used by lecturers to develop digital competencies so that the digital modes used by each lecturer can be more varied. It aims to avoid student boredom in learning and absorb information related to teaching materials (Al-Maroof \& Al-Emran, 2018).

There are ten participants in this study, five female and five male respondents. A pseudonym was assigned to each of the participants. $P 1, P 2, P 3, P 4, P 5, P 6, P 7, P 8, P 9$, and $P 10$ were the participants.

After the participants were given ten questions about the use of information technology in online learning at Muhadi Setiabudi University, some participants argued about the unpreparedness of the facilities they had to take online lectures during the Covid-19 pandemic. Students at Muhadi Setiabudi University did not yet have a laptop and tended to use cellphones as a facility to take online lectures.

As one of the respondents noted:

It was difficult for me to take online lectures during the pandemic because I did not have any laptop for online lectures. (P1).

I use my cellphone to take part in a zoom meeting. It is a bit difficult. However, it cannot be helped, and I still have to attend lectures so that grades are not bad. (P2).

Participants argued about the challenge of online recovery, namely the unpreparedness to carry out online lectures because it was a new thing that previously always carried out lectures face-to-face with lecturers in the class. 
452 Utilization of Information Technology during the Covid-19 pandemic: Student's Perception of Online

Lectures - Ubaedillah, Damar Isti Pratiwi

DOI: https://doi.org/10.31004/edukatif.v3i2.320

As one of the interviewees maintained:

The first time I studied online, I was confused about what to do. Before, I had never studied online before covid recovery was carried out face-to-face in class. (P3).

Before college was not like this when I was online, I was not satisfied. It differs by fitting face to face. I can quickly study face-to-face (P4).

It is the first time for me. Lectures do not meet face to face with friends and lecturers. It was not very easy, especially for discussions in online classes, and I was disconcerted. (P5).

Participants argued about the challenges of online recovery, namely difficulties in using internet connections and wasteful data. Some students do not live in urban areas, while the only internet connection is from a cellphone.

One of the respondents noted that:

I live in a rural area, so the signal at my home is complex. It makes it difficult for me to attend online tuition. (P6).

I cannot attend lectures when I do not have an internet quota, and there is not even wifi in my area. Moreover, the quota is expensive, and the person has a free quota from campus every month. (P7).

The signal at my home is complex. Sometimes I have to be absent because I cannot take online lectures. (P8).

Online lectures are different from regular lectures. Apart from having to pay tuition fees, students must also buy a quota to attend college. That is not very easy. (P9).

Based on the questionnaire data, information was obtained about online lectures during the Covid-19 pandemic that there were still many Muhadi Setiabudi University students who were not ready for online lectures.

Table 1. Challenges faced by Students

\begin{tabular}{c|c|c|c}
\hline Number & Theme & $\begin{array}{c}\text { Number of participants } \\
\text { mentioning the theme }\end{array}$ & $\begin{array}{c}\text { Percentage of the participants } \\
\text { mentioning the theme }\end{array}$ \\
\hline 1 & Do not have laptop facilities & 10 & $50 \%$ \\
\hline 2 & $\begin{array}{c}\text { Only use cellphone facilities in } \\
\text { online lectures }\end{array}$ & 10 & $50 \%$ \\
\hline 3 & $\begin{array}{c}\text { We had never conducted online } \\
\text { lectures before Covid-19, }\end{array}$ & 10 & $61.5 \%$ \\
\hline 4 & $\begin{array}{c}\text { Difficult to get an internet } \\
\text { connection }\end{array}$ & 10 & $80 \%$ \\
\hline 5 & Wasteful in using data packages & 10 & $80 \%$ \\
\hline
\end{tabular}

Based on table 1 above, it can be seen that $50 \%$ of students stated that they do not have laptop facilities, and $50 \%$ of students in online lectures use cellphones as a medium for online lectures. Based on the results of a survey of students, it was found that $61.5 \%$ of students before Covid-19 had never conducted online learning. This student unpreparedness was also caused by Muhadi Setiabudi University students' geographical location who mainly were far from cities, so many students had difficulty getting an internet connection. Based on the survey results, it was found that as many as $80 \%$ of students experienced problems with signal 
problems and wasteful use of data packages when carrying out online lectures. This data indicates that many students have struggled to get the most out of online lectures.

The online lecture process has not been carried out optimally because of lecturers' unpreparedness and students, so that it needs adjustments first. Many students have limited facilities to support online lectures. It starts from the limited signal, wasteful data bundles, many students without computers, and many students who do not live in cities but remote/mountainous areas far from internet access. As a consequence of this situation, there is now a more significant learning distance.

Although it is not difficult to change the conventional learning paradigm online, it will take a long time because it is closely related to the paradigm shift in academic culture. The survey data above shows that students are not ready to carry out this online learning because it involves academic culture, including values, attitudes, knowledge, skills, and facilities and infrastructure related to information literacy (Wankel, 2009). Ideally, this policy change concerning the learning paradigm is used as a momentum for students to freely and critically seek knowledge digitally. (Wang et al., 2011) Likewise, learning opportunities can be free because they are not bound by a face-to-face presence (Hamat \& Hassan, 2019). Students can manage their time freely to fulfill their study assignments. Thus, students will become literate with information related to their academic needs and continue to grow (Bal, 2018). It is an essential concern for the Muhadi Setiabudi University institution because many students expect to get subsidized administrative costs. Given that it is uncertain when lectures will normally run again.

Conventional systems that have occurred so far should be integrated with multimedia communication media, especially since the discovery of this multimedia communication media. Due to the nature of the internet that can be contacted at any time, students can take advantage of the educational programs provided on the internet at any time according to their spare time so that space and time constraints they face in finding learning resources can be overcome. With the rapid development in telecommunication, multimedia, and information technology, listening to lectures, taking notes on paper is undoubtedly out of date. According to (Boonmoh et al., 2021), there is a classification of the use of ICT (Information, Communication, and Technology) into three types, namely: first, ICT as a medium (aids) of education, which is only as a complement to clarify the description given. Second, ICT as a source, namely as a source of information and seeking information. Third, ICT as a learning system.

Various online learning models have emerged in line with ICT development (Information, Communication, and Technology). Furthermore, web-based school (web-school) or internet-based school (cyber-school) uses internet facilities. Various new terms emerged in learning using the internet, such as online learning, distance learning, web-based learning, e-learning (Brown et al., 2015). The rapid development of technology is currently the gateway for the arrival of industrial revolution 4.0 or industry 4.0. According to (Davis 2011) industry, 4.0 is a cyber-physical system, which means technology is no longer a 'tool' but is embedded in people's lives. Artificial Intelligence, nanotechnology, biotechnology, autonomous vehicles, and 3D printing are examples of today's overall technology development. Speed, reach / coverage, and impact are three reasons from Schwab(Forum, 2016), which explains that the current technological transformation is not an extension of the third industrial revolution, but the arrival of the industrial revolution 4.0.

The previous study (Budianto \& Arifani, 2021) concentrated exclusively on WhatsApp information technology usage and did not address other information technology for the learning process. The purpose of the research only focused on secondary school education, which was different from this research which addressed the broader use of information technology and focused on college research. The results of this study can be used as evaluation material for online class learning at the college level and can be considered in 
454 Utilization of Information Technology during the Covid-19 pandemic: Student's Perception of Online Lectures - Ubaedillah, Damar Isti Pratiwi

DOI: https://doi.org/10.31004/edukatif.v3i2.320

choosing the use of information technology and students' needs in the implementation of online lectures during the Covid-19 pandemic.

\section{CONCLUSION}

The Covid-19 pandemic had had a significant effect on Indonesian higher education, including Muhadi Setiabudi University. Using information technology such as WhatsApp party, Edmodo, EdLink, Moodle, Google Classroom, and Schoology online class to enforce the physical distancing policy becomes the foundation for introducing online lectures. Since this application is difficult to use, the Whatshap community and Google Classroom are the most commonly used media in online learning at Muhadi Setiabudi University. However, some barriers exist, such as insufficient facilities.

According to the survey results, $50 \%$ of students do not have laptops and depend solely on cellphones for lectures, and $80 \%$ of students said it was difficult to get a signal and that it was wasteful to use data packages because many students live outside of cities. Many people believe that online lectures are ineffective because they are not used to giving them, so they need to make some changes. It is also because 61.5 percent of students said they had never used online lecture media before the Covid-19 pandemic. In several ways, it is clear that Covid-19 is a tragedy that affects almost every area of human life, including education. However, it cannot be denied that the Covid-19 pandemic has created opportunities for educational institutions to become more technologically literate, with the implementation of online lectures catalyzing speeding up the process of Indonesian education's digital transformation. Previously, numerous discourses, enabling policies, and socialization about the industrial age 4.0 had failed to substantially progress in the digital transformation of Indonesian education, Covid-19 or the Corona Virus, for colleges, institutes, polytechnics, academies, and high schools. It has had a significant effect on the digital transformation of education in the 4.0 period.

\section{REFERENCES}

Al-Maroof, R. A. S., \& Al-Emran, M. (2018). Students Acceptance of Google Classroom: An Exploratory Study using PLS-SEM Approach. International Journal of Emerging Technologies in Learning, 13(6).

Atmojo, A. E. P., \& Nugroho, A. (2020). EFL Classes Must Go Online! Teaching Activities and Challenges during COVID-19 Pandemic in Indonesia. Register Journal, 13(1), 49-76. https://doi.org/10.18326/rgt.v13i1.49-76

Boonmoh, A., Jumpakate, T., \& Karpklon, S. (2021). Teachers' perceptions and experience in using technology for the classroom. Call-Ej, 22(1), 1-24.

Brown, M., Hughes, H., Keppell, M., Hard, N., \& Smith, L. (2015). Stories from Students in Their First Semester of Distance Learning. International Review of Research in Open and Distributed Learning. International Review of Research in Open and Distributed Learning, 16(4), 1-17.

Budianto, L., \& Arifani, Y. (2021). Utilizing WhatsApp-driven learning during the covid-19 outbreak: Efl users' perceptions and practices. Call-Ej, 22(1), 264-281.

Creswell, J. W. (2014). A concise introduction to mixed methods research. SAGE publications.

Culp, W. C. (2020). Coronavirus Disease 2019: In-Home Isolation Room Construction. A\&A Practice, 14(6), e01218. https://doi.org/10.1213/XAA.0000000000001218

Durriyah, T. L., \& Zuhdi, M. (2018). Digital literacy with EFL student teachers: exploring Indonesian student teachers' initial perception about integrating digital technologies into a teaching unit. International Journal of Education and Literacy Studies, 6(3), 53-60.

Fauzi, A. (2017). The effect of Edmodo on students' writing skill in recount text. International Journal of 
455 Utilization of Information Technology during the Covid-19 pandemic: Student's Perception of Online Lectures - Ubaedillah, Damar Isti Pratiwi

DOI: https://doi.org/10.31004/edukatif.v3i2.320

Pedagogy and Teacher Education, 1(2), 73-79.

Forum, W. E. (2016). The future of jobs: Employment, skills and workforce strategy for the fourth industrial revolution. Global Challenge Insight Report.

Gon, S., \& Rawekar, A. (2017). Effectivity of E-Learning through Whatsapp as a Teaching-Learning Tool. MVP Journal of Medical Sciences, 4(1), 19. https://doi.org/10.18311/mvpjms/0/v0/i0/8454

Hamadeh, W. (2020). Using Social Media to Enhance Second Language Learning. Computer-Assisted Language Learning Electronic Journal, 21(2), 132-149.

Hamat, A., \& Hassan, H. A. (2019). Use of social media for informal language learning by Malaysian University Students. 3L: Language, Linguistics, Literature, 25(4), 68-83. https://doi.org/10.17576/3L2019-2504-05

Iftakhar, S. (2016). Google Classroom: what works and how. Journal of Education and Social Sciences, 3(1), $12-18$.

Khoshnevisan, B. (2020). [ Software Review ] Technological Tools to Empower Teachers in Third-World Countries: Mobile Teacher App Mobile Teacher. Computer-Assisted Language Learning Electronic Journal(CALL-EJ), 22(1), 347-354.

Kodrat, D. (2021). Management of The Main Course Learning Management System (LMS) By Lecturers In Promoting A Quality Class. UICELL Conference Proceeding, 114-120.

Mendikbud. (2020). Surat Edaran Nomor 4 Tahun 2020 tentang Pelaksanaan Kebijakan Pendidikan dalam Masa Darurat Penyebaran Coronavirus Disease (COVID-19).

Nashir, M., \& Laili, R. N. (2021). EDUKATIF : JURNAL ILMU PENDIDIKAN English Teachers' Perception toward the Switch from Offline to Online Teaching during the lockdown in the Midst of Covid-19 Outbreak Abstrak. 3(2), 250-260. https://doi.org/https://doi.org/10.31004/edukatif.v3i2.287

Safdari, M. (2021). Contributions of Edmodo social learning network to Iranian EFL learners' writing accuracy. Call-Ej, 22(1), 355-373.

Shams-Abadi, B. B., Ahmadi, S. D., \& Mehrdad, A. G. (2015). The effect of Edmodo on EFL learners' writing performance. International Journal of Educational Investigations, 2(2), 88-97.

Tirziu, A.-M., \& Vrabie, C. (2015). Education 2.0: E-learning methods. Procedia-Social and Behavioral Sciences, 186, 376-380.

Traxler, J. (2018). Distance learning-Predictions and possibilities. Education Sciences, 8(1). https://doi.org/10.3390/educsci8010035

Velavan, T. P., \& Meyer, C. G. (2020). The COVID-19 Epidemic. Tropical Medicine and International Health, 25(3), 278-280. https://doi.org/https://doi.org/10.1111/tmi.13383

Wang, Q., Chen, W., \& Liang, Y. (2011). The Effects of Social Media on College Students. MBA Student Scholarship, 5, 13. https://doi.org/10.1111/j.1548-1379.2010.01107.x

Wankel, C. (2009). Management education using social media. Organisation Management Journal, 6(4), 251262. https://doi.org/10.1057/omj.2009.34

Zam Zam Al Arif, T. (2019). the Use of Social Media for English Language Learning: an Exploratory Study of EFL University Students. Metathesis: Journal of English Language, Literature, and Teaching, 3(2), 224-233. https://doi.org/10.31002/metathesis.v3i2.1921 